\title{
How caimans protect fish stocks in western Brazilian Amazonia - a case for maintaining the ban on caiman hunting
}

\author{
Carlos A. Peres and Anina M. Carkeek
}

Rubber tapper communities along the large white-water rivers of central-western Brazilian Amazonia rely heavily on local fish stocks all year round. This subsistence fishing faces severe competition from commercial fishing boats from urban centres, which in some areas have over-fished the economically most important fish species. In the Juruá River and its oxbow lakes, two species of freshwater crocodilians - the black and the spectacled caiman - indirectly benefit subsistence fishermen by disrupting commercial fishing operations. The gill-nets used by commercial fishing boats are often damaged beyond immediate repair by the caimans as they make easy pickings of the catch. This appears to deter overharvesting of important fish stocks in many sections of the river. In contrast, subsistence fishermen use fishing gear that is rarely damaged by caimans. It would seem that caimans at their present numbers offer protection to local fish stocks by reducing the efficiency and financial viability of commercial fisheries, which would otherwise rapidly reduce fish yields for local rubber tappers.

\section{Caimans - a history of exploitation}

The black caiman Melanosuchus niger and spectacled caiman Caiman crocodilus - once commonly seen along the banks of the large rivers of Amazonia - have disappeared from many parts of the region. During the mid-1800s, when caimans were treated as pests to be eliminated, Bates (1863) wrote, 'the waters of the Solimoes (upper Amazon) are as well stocked with large alligators in the dry season, as a ditch in England is in summer with tadpoles'. Earlier this century, however, the caiman-leather industry, and to a lesser extent, the use of oil extracted from caimans mixed with kerosene to power generators for lighting (Pereira, 1944), substantially reduced caiman populations in the Amazon. Between 1960 and 19694.5 million Melanosuchus and Caiman skins were exported from Brazil (1.5 million of them from the Amazon) (Smith, 1981), a decline from 7.45 million in the preceding 10 years (Carvalho, 1967). Another 53,433 skins left Peru between 1962 and 1964, a large pro- portion of which derived from Brazilian Amazonia (Dourojeanni, 1974).

\section{Introduction of the caiman-hunting ban}

Caiman hunting and hide-trade in Brazil were outlawed in 1967 by a ban on wildlife exploitation and commerce (Decreto Lei 5.197), but trade was allowed to continue for a few more years to clear old stockpiles. The ban has been largely effective, cutting down the national caiman-hide industry, increasing the risk of traders being penalized, and curbing the incentives of harvesting and processing skins in Brazil. The caiman slaughter, however, continued more or less unabated in areas where skins can be smuggled via neighbouring countries, where they can fetch higher prices because of poorly enforced or non-existent trade regulations. For example, an estimated 1 million caiman skins are smuggled out of the Brazilian Pantanal wetlands every year (Gaski and Hemley, 1988) and at least 1,180,153 (but 
probably more than 2 million) caiman hides were exported through Colombia during a 30month period from January 1976; a large proportion of these were from Brazilian Amazonia (Medem, 1980). To date, Bolivia and Paraguay continue to export skins of caimans poached in Brazil (Mittermeier et al., 1990), albeit to an unknown extent because statistics of confiscated shipments from occasional seizures probably represent only a small tip of the illegal trade iceberg.

In Amazonia commercial hide-hunting of these much feared and poorly understood crocodilians started in the 1930s (Plotkin et al., 1983), and for several decades focused almost entirely on the black caiman. This species was preferred by hunters and tanners because it is larger and has a less ossified skin than the spectacled caiman (Magnusson, 1982). As black caiman numbers dwindled, there was a shift in the hide industry to the more common spectacled caiman, which in the early 1970s was hunted on a scale similar to that which had decimated their larger counterparts. Spectacled caimans appear able to sustain larger populations than those of black caimans under comparable hunting pressure because they are recruited into the breeding populations before they grow into size-classes preferred by hunters (Rebêlo and Magnusson, 1983; Herron, 1991).

In some areas large numbers of caimans are still regularly poached, mainly for their tail meat, which is salted, dried and sold in city markets as catfish or pirarucú (Arapaima gigas, Osteoglossidae) meat, which is prepared in a similar manner (Best, 1984; C. A. Peres, unpubl. data).

\section{Calls for lifting the ban on caiman hunting}

In many sections of the Amazon and its major tributaries, however, small-scale hunting has not prevented a noticeable population recovery in both the caiman species. Greater numbers of these large predators in the rivers have also increased the frequency of attacks on local people, which have resulted in oc- casional but much publicized minor casualties and, in rare cases, fatalities. The alarm raised by local community leaders and politicians as a result of incidents of this nature eventually triggered immense regional pressure on central government to reform legislation protecting caimans in Amazonia. This has been chiefly endorsed by local and regional politicians opposing Amazonian conservation interests. However, proposals to abolish hunting restrictions on 'this commercially lucrative enemy of man, which has maimed thousands of Brazilians' (Anon., 1990) have been vehemently opposed by a number of leading Brazilian environmentalists. This created a clash between Amazonian politicians and the Brazilian Institute for the Environment and Renewable Natural Resources (IBAMA). In a wider political scenario this still unresolved conflict has been incorporated by both sides of the national debate on development versus protection of Amazonian wildlands and natural resources, and to a certain extent presents a test case for Brazilian commitment to Amazonian conservation.

This paper briefly outlines the effect of large-bodied crocodilians on the interaction between subsistence and commercial fishing in western Brazilian Amazonia. It is based on vertebrate surveys conducted during 15 months between 1987 and 1992 along the entire Juruá River basin, in the states of Amazonas and Acre. We challenge political views that caimans pose a long-term competitive or dangerous threat to local inhabitants who rely heavily on fish stocks as a vital source of subsistence. Finally we suggest that if the ban on harvest and trade of Amazonian caiman skins were lifted, it might be of shortterm benefit to commercial fisheries but detrimental to local subsistence fishermen.

\section{Fishing in the Juruá River}

The Juruá River is one of the largest whitewater tributaries of the Amazon. A wide band of seasonally flooded (várzea) forest borders its meanders, anastomosing channels and oxbow lakes (Figure 1). The highly productive natural 
stands of rubber trees (Hevea spp. Euphorbiaceae) in this basin attracted thousands of north-eastern Brazilian immigrants in the mid-1800s, which led to the over-harvest of several commercially valuable fish and reptile species. Small communities of rubber-tappers (seringueiros) along the river remain heavily reliant upon aquatic sources of protein all year round.

Following the collapse of rubber prices in world markets large numbers of seringueiros moved to urban centres. The impact of subsistence fishing has thus decreased but it has been substantially outweighed by the increase from commercial fisheries stimulated by swollen urban demands. Towns in the Juruá (and large cities with which they trade) are supplied with large quantities of fish by commercial fishing boats, which compensates for the relatively small protein supply offered by local cattle-ranching and other livestock practices. The increasing impact of commercial fisheries is reflected in the fact that local rubber-tappers and landlords now ascribe enormous importance to protecting lakes against outside intruders (E. Whitesell, unpubl. data).

Fish are the main source of protein to seringueiros throughout the Juruá basin, even though yields are low in the headwaters above Cruzeiro do Sul, where floodplains are less extensive or non-existent. Subsistence fishing is usually carried out on a daily basis and tends to result in small catches used by one or a few households. A wide range of fishing techniques is employed depending on the season of the year and the target species, and includes the use of harpoons, bows-and-arrows, trident spears, fencing, and hooked lines

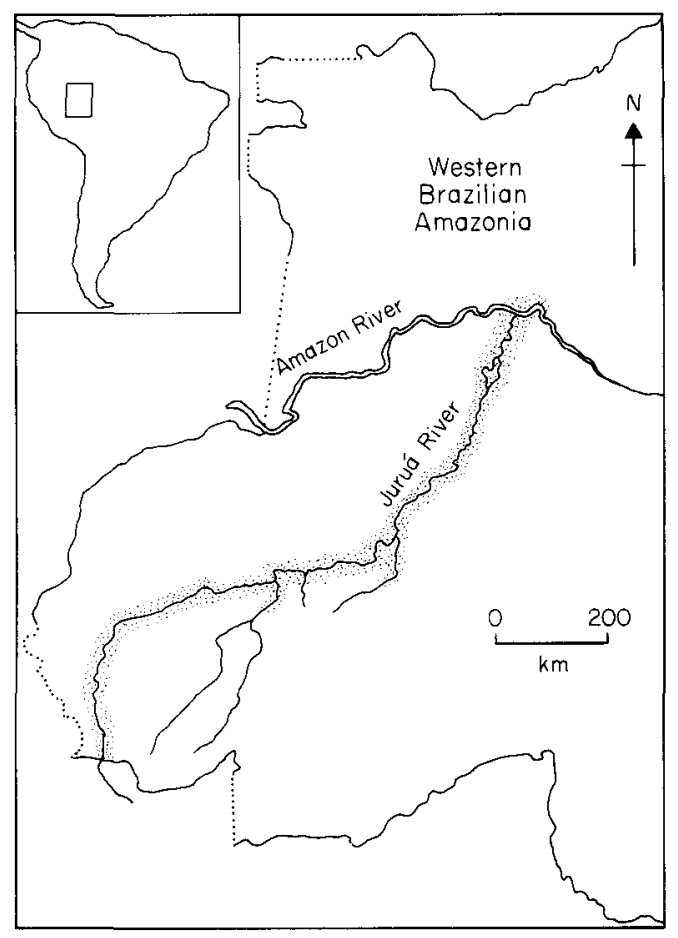

Figure 1. Location of the Jurua River in western Brazilian Amazonia. Shaded area indicates seasonally flooded (várzea) forests along the river

with single and multiple (espinheis) hooks. The only widely used fishing gear involving nets consists of cast-nets (tarrafas), which are made locally with nylon line and are relatively cheap. These are used in shallow waters and do not come into conflict with either caiman species.

Commercial fishing boats mainly use 20-50$\mathrm{m}$ long gill-nets (malhadeiras) deployed in the river channel or adjacent lakes. This type of
Dry-season view of a meandering river channel segment of the central-lower Juruá River, downriver from Carauarí, Amazonas.

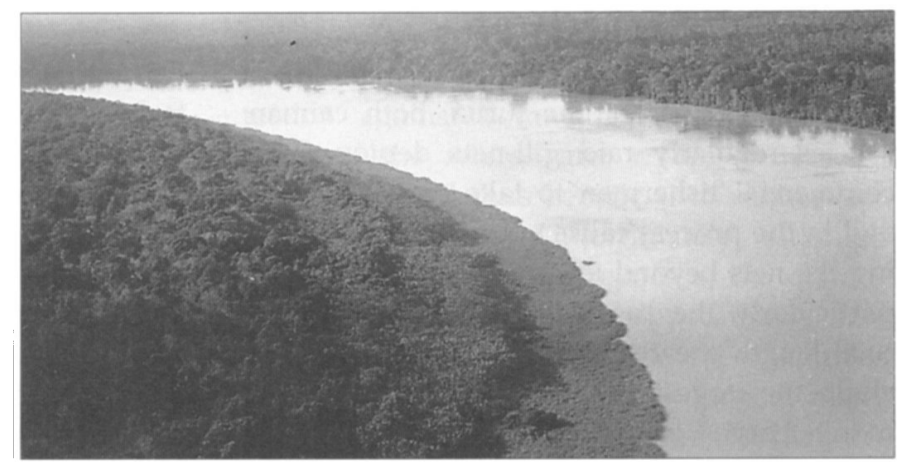




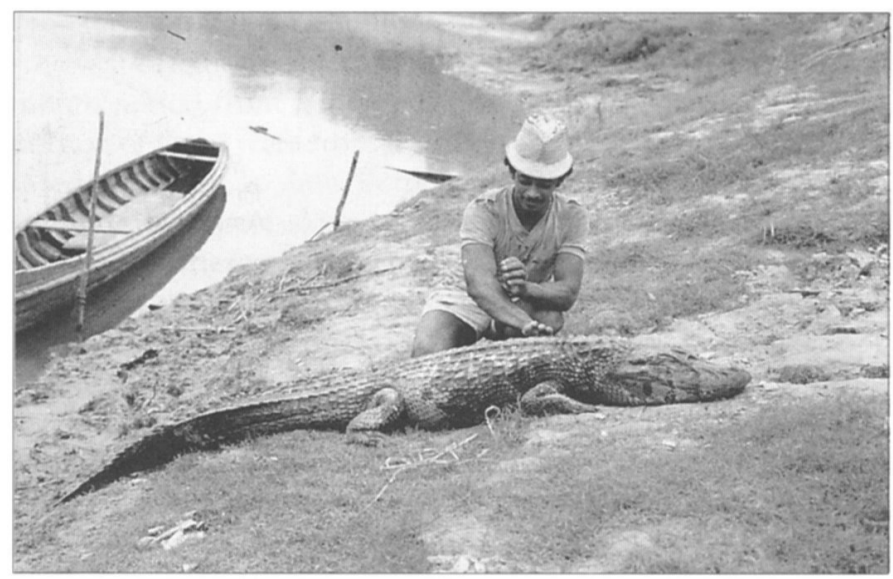

Large crocodilians, such as this 2.3-m long black caiman, are still relatively common along major sections of the Juruá River, where they indirectly protect local fishermen against over-fishing by outside commercial fisheries.

fishing gear accounts for the bulk of the fish landed in the Manaus fish market (Petrere, 1982). Fishing vessels equipped with gill-nets operate mainly during a 6-month period around the dry season, when fish stocks are concentrated in the river channel and oxbow lakes. These boats are equipped with large ice compartments or freezers, which are used to store commercially important fish species, such as large serrasalmine characoids (particularly tambaqui Colossoma macropomum and pirapitinga (. bidens). Between 1976 and 1978, these two species accounted for 85-89 per cent of the commercial catch from the Juruá River landed in Manaus (representing 1200-1600 tonnes of fish), a greater proportion than that from any other major tributary of the centralwestern Amazon (Petrere, 1985). Indeed, it is widely recognized by local people that the size of individual Colossoma in both commercial and subsistence catches in the Juruá has decreased year after year.

\section{Caiman/fisheries interactions}

In many sections of the Juruá, both caiman species regularly raid gill-nets deployed by commercial fishermen to take easy pickings, and in the process cause severe damage, leaving the nets beyond immediate repair. This is particularly the case where caimans with a total length greater than $2 \mathrm{~m}$, which may include the largest $C$. crocodilus, are still common. Large black caimans, which may reach $4.5 \mathrm{~m}$ in several parts of the Juruá, are capable of destroying entire gill-nets in such a raid. Local opinion suggests that the frequency of gill-net raids is high enough to discourage this form of fishing. In at least some sections of the river, for example, more than half of the gill-nets operated overnight are ruined by caimans (E. Machado, pers. comm.). As a result, many fishing trips have had to be aborted, or have been made considerably less profitable because of decreased yields and increased net repair costs. Indeed, many fishing boats have been reluctant to return, which has substantially hampered the success and financial viability of commercial fishing operations. As a result commercial fishermen are antagonistic towards caimans and many medium-sized to large individuals are shot on sight. However, such sporadic culling appears to have been ineffective in reducing their numbers in large sections of the river.

\section{Caimans - a threat to human life?}

Despite alarming reports of a few recent attacks on non-tribal Amazonians, caimans generally pose little or no threat to local inhabitants. Authenticated records of Neotropical crocodilian attacks on people are extremely rare (e.g. Hall, 1991). We estimated that, for the human population of the combined municipal areas of Carauarí and Eirunepé, the rate of confrontations leading to minor or fatal casualties is only 0.17 cases per 1000 inhabi- 
tants per year (C. A. Peres and A. M. Carkeek, unpubl. data). The frequency of attacks in other parts of Amazonia is reportedly higher (e.g. Nhamundá, Amazonas; 12.9 cases per 1000 inhabitants in 1991: P. Baranda, pers. comm.), but these could not be confirmed independently by state or research authorities based in Manaus (W. Magnusson, pers. comm.). These cases have been exaggerated by local and regional politicians favouring an end to the ban on the commercial harvest of caimans. In any case, local people throughout the Amazon have always controlled caiman numbers to a certain extent by eliminating problem animals, and will continue defending themselves in this way regardless of any hunting regulations.

Caimans may play an important regulatory role within fish communities (Glasser, 1979), as they switch to predatory fish species, which may be ignored by fishermen but that can cause a profound imbalance in the pattern of species abundance in the community (but see Magnusson, 1990). Fittkau (1970) argued that they also provide other important, but poorly understood, ecological services in Amazonian lakes, such as increasing primary productivity through the recycling of nutrients made available in their excretory byproducts (but see Gorzula, 1987). In addition, Melanosuchus niger and Caiman crocodilus feed on an extremely wide range of vertebrate prey items and carrion (Staton and Dixon, 1975; Otte, 1978), which suggests, (i) a low overall overlap between the fish species they eat and those of typical subsistence or commercial catches (Petrere, 1982) and, (ii) little feeding competition between caimans and people.

\section{The case against lifting the ban on caiman hunting}

We predict that lifting the ban on commercial hunting of caiman, and permitting lucrative caiman skin exports, will result in over-harvesting and ultimately extirpation of all but the smaller, non-breeding individuals. This is most likely to occur where populations are restricted to the course of a single river and its

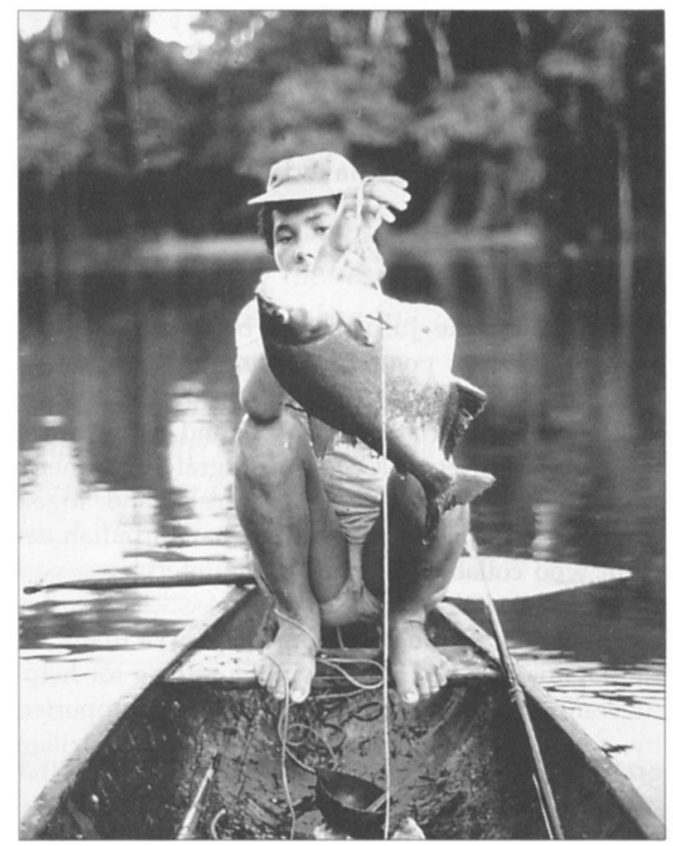

Traditional subsistence practices by seringueiros, such as the skilful use of locally manufactured bowand-arrows, are highly effective for small-scale catches in oxbow lakes, like this forest-feeding characoid (pirapitinga, Colossoma bidens). Such fishing methods do not conflict with caimans.

associated channels and lakes, which offer fewer refugia than large wetland systems, such as the Brazilian Pantanal. Once caiman numbers are reduced there would be an invasion of commercial fishing vessels, which would subsequently over-harvest many of the important fish species that are so vital for local people. Such unequal competition, at least throughout most of the Juruá, would be immensely detrimental to small-scale fishermen, who would remain powerless to protect their own sources of subsistence. Large caimans, therefore, would appear to be an effective protection against commercial over-fishing in some of the white-water rivers of western Amazonia, and thus beneficial to rubber-tapping communities. Unfortunately, although local fishermen usually rejoice at the disruption of commercial fishing by caimans, few seem to understand the role these animals play in curbing over-fishing - indeed, many profoundly dislike them. We suggest that, de- 
spite the popular poor reputation of caimans, the interactions described in this paper and their implications should be given careful consideration before current restrictions on caiman hunting are relaxed.

\section{Acknowledgments}

Fieldwork on the Juruá River between 1987 and 1992 was made possible by grants from World Wildlife Fund-US (Project 6199), Wildlife Conservation International (WCI), and the National Geographic Society (NGS). We are grateful to members of the WCI-NGS Juruá Project, and to all seringueiros of north-eastern Brazilian or indian descent who collaborated during the interviews, particularly the leaders of the Associação dos Pescadores of Carauarí and Eirunepé. We thank W. E. Magnusson and an anonymous referee for helpful comments on this manuscript. CAP is supported by a post-doctoral fellowship from the Brazilian Science and Technology Council (CNPq).

\section{References}

Anon., 1990. A vote against the Amazon. Newsweek, 22 October 1990.

Bates, H.W. 1863. The Naturalist on the River Amazon. John Murray, London.

Best, R.C. 1984. The aquatic mammals and reptiles of the Amazon. In The Amazon: Limnology and Landscape Ecology of a Mighty Tropical River and its Basin (ed. H. Sioli), pp. 371-412. W. Junk, Dordrecht, The Netherlands.

Carvalho, J.C. 1967. A conservação da natureza e recursos naturais na Amazônia brasileira. Atas do Simpósio sobre a Biota Amazónica, 7, 1-47.

Dourojeanni, M.J. 1974. Impacto de la producción de la fauna silvestre en la economía de la Amazonía peruana. Rev. For. Perú, 5, 15-27.

Fittkau, E.J. 1970. Role of caimans in the nutrient regime of mouth-lakes of Amazon affluents (an hypothesis). Biotropica, 2, 138-142.

Gaski, A. and Hemley, G. 1988. The ups and downs of the crocodilian skin trade. WWF-TRAFFIC Newsletter, 8 (1), 14.

Glasser, J.W. 1979. The role of predation in shaping and maintaining the structure of communities. Am. Nat. 113, 631-641.

Gorzula, S. 1987. The management of crocodilians in Venezuela. In Wildlife Management: Crocodiles and Alligators (eds G. J. W. Webb, S. C. Manolis and P. J. Whitehead), pp. 91-101. Surrey Beatty \& Sons, Chipping Norton.

Hall, P.M. 1991. Dangerous to man? A record of an attack by a black caiman (Melanosuchus niger) in
Guyana. Herp. Review, 22 (1), 9-11.

Herron, J.C. 1991. Growth rates of black caiman Melanosuchus niger and spectacled caiman Caiman crocodilus, and the recruitment of breeders in hunted caiman populations. Biol. Conserv. 55, 103-113.

Magnusson, W.E. 1982. Biological aspects of the conservation of Amazonian crocodilian in Brasil. In Crocodiles: Proceedings of the 5th Working Meeting of the Crocodilian Specialist Group of the Species Survival Commission of IUCN, pp. 108-116. IUCN, Gland.

Magnusson, W.E. 1990. Book review: Crocodiles, by R. Steel. Copeia, 1990, 1185-1187.

Medem, F. 1980. Caimans and crocodiles - a tale of destruction. Oryx, 15, 390-391.

Mittermeier, R.A., Câmara, I.G., Pádua, M.T.J. and Blanck, J. 1990. Conservation in the Pantanal of Brazil. Oryx, 24, 103-112.

Otte, K.C. 1978. Untersuchungen zur biologie des Mohrenkaiman (Melanosuchus niger Spix 1825) aus dem Nationalpark Manu (Peru): Beitrage zu Morphologie, Physiologie, Ethologie and Okologie, München.

Pereira, N. 1944. A utilização da carne do jacaré na Amazônia. Bol. Geogr. Rio de J. 2, 150-152.

Petrere, M., Jr. 1982. Ecology of the Fisheries in the River Amazon and its Tributaries in the Amazonas State (Brazil). PhD thesis, University of East Anglia, Norwich.

Petrere, M., Jr. 1985. A pesca commercial no Rio Solimões-Amazonas e seus afluentes: análise dos informes do pescado desembarcado no Mercado Municipal de Manaus (1976-1978). Ciência $e$ Cultura, 37, 1987-1999.

Plotkin, M.J., Medem, F., Mittermeier, R.A. and Constable, I.D. 1983. Distribution and conservation of the black caiman Melanosuchus niger. In Advances in Herpetology and Evolutionary Biology (eds A. G . J. Rhodin and K. Miyata), pp. 695-705. Museum of Comparative Zoology, Cambridge, MA.

Rebêlo, G.H. and Magnusson, W.E. 1983. An analysis of the effect of hunting on Caiman crocodilus and Melanosuchus niger based on the sizes of confiscated skins. Biol. Conserv. 26, 95-104.

Smith, N.J.H. 1981. Caimans, capybaras, manatees, and man in Amazonia. Biol. Conserv. 19, 95-104.

Staton, M.A. and Dixon, J.R. 1975. Studies on the dry season biology of Caiman crocodilus crocodilus from the Venezuelan Ilanos. Mem. Soc. Cienc. Nat. La Salle, 101, 237-264.

Carlos A. Peres and Anina M. Carkeek, Museu Goeldi, Departamento de Zoologia, Cx. Postal 399, Belém, Pará 66.040, Brazil. 